\title{
Energy-Protein-Consentrate as Product of Glucosamine Extract from Shrimp Waste on Performance Ofnative Chicken
}

\author{
Abun $^{1}$, Deny Saefulhadjar ${ }^{1}$, Tuty Widjastuti ${ }^{1}$, Kiki Haetami ${ }^{2}$, Rachmat Wiradimadja ${ }^{1}$ \\ ${ }^{1}$ Faculty of Animal Husbandry, Padjadjaran University, Padjadjaran University, Street Bandung-Sumedang KM. 21, 45363, \\ Sumedang-West Java, Indonesia \\ ${ }^{2}$ Faculty of Fisheries and Marine Science, Padjadjaran University, Street Bandung-Sumedang KM. 21, 45363, Sumedang- \\ West Java, Indonesia
}

\begin{abstract}
Material shrimp waste contains a lot of liquid extract dissolved nutrients, especially protein primary metabolite degraded, the process of protein back into a higher structure in the form of glucosamine will have a biological value as a source of energy-protein concentrate. Chitin Extraction of shrimp waste was done microbiologically using Bacillus licheniformis and Lactobacillus sp.
\end{abstract}

Ration is a major determinant in the maintenance of super chicken intensive system, as the provision of energy and protein for growth. This research was aim to feeding trial of EPC product (energy-protein concentrates) on ration chick nature through performance measured (consume of ration, weight gain, and feed efficiency), and choice level of EPC product on ration through measure carcass production (weight of carcass). The trial used Completely Randomized Design (CRD). Statistic data analyzed was used variants, followed by Duncan Multiple Range Test.

The result indicated that:

1. The use of energy-protein concentrates (EPC) in anative chickenration feed consumption resulted in the same response.

2. The use of energy-protein concentrates (EPC)in a chicken feed at a rate of $3 \%$ can increase weight gain, live weight and carcass weight, and efficiency offeed utilization.

3. Rations containing $18.5 \%$ crude protein and metabolizable energy 2,800 kcal / kg which iscoupled with the EPC3\% yield performance of the supernative chicken which is equivalent to the standard diet (20.5\% crude protein and metabolizable energy of 3,000 kcal / kg).

Keywords-Shrimp waste, glucosamine, energy-protein concentrate, efficiency of ration, chick region.

\section{INTRODUCION}

Rations are the deciding factor to growth, in addition to the treatment of seeds and livestock breeding. The optimal performance of poultry, especially chick region can only be realized if given rations of quality that meet certain requirements in sufficient quantities and balanced. Fulfillment of nutrients in the diet can be done by adding energy-protein concentrates (EPC). It was necessary because EPC can improve feed efficiency, and quality of chicken meat.

Waste extraction of chitin from shrimp shells mainly primary protein metabolites that are not degraded biologically valuable as a source of feed nutrients. This material be helpful if denaturize process of protein back into a higher protein structure in the form of glucosamine that has biological value to support the growth and quality of chicken meat.

Potential nutrient extraction of chitin liquid products were great but not yet ready, because the functional group formed strung yet complete, so it must denaturize use of certain ions as binder and the functional group becomes functional. Binders which can be used is a compound containing sulfate ions, such as ammonium sulfate, potassium sulfate, and sodium sulfate hydro. Sulphate ions of all these compounds can bind glucosamine formed from chitin extraction process and form the functional nutrients glucosamine.

The nature of glucosamine formed from the binding process by the sulphate ions of different chemical compounds will be different. The temperature and time effect on the binding process Functional glucosamine products produced. Glucosamine is produced can be neutral, acidic or alkaline. The acidic nature of an effect on the nutritional value of glucosamine produced.

Glucosamine is produced from the binding process (bordering/naturation) is in the form of a viscous liquid that could potentially easily damaged if not immediately preserved. Pickling can be done is cooling or drying. 
Refrigeration requires a place and a great energy for the engine coolant, as well as when dried directly, because the process is long. Mixing with other materials, such as feed ingredients source of carbohydrates, is a good alternative. Water from the media glucosamine carbohydrates can be absorbed by the material, making it easier and faster in the subsequent drying process. The final material is formed into a carbohydrate-rich feed ingredients glucosamine well as protein source, so it can be called energy-protein concentrates (EPC).The extraction of chitin are chemically has several weaknesses, which cause environmental damage caused by chemical waste generated, occurs corrosive very high, and the occurrence of depolymerization due to excessive cutting molecular structure of proteins, minerals and vitamins. To overcome these shortcomings, the extraction of chitin done microbiology, using the services microbe to produce a protease enzyme (Bacillus licheniformis) and acid fermentation (Lactobacillus sp).

Shrimp shell contains minerals by 30 to $50 \%$ (dry weight), the main composition is calcium carbonate and calcium phosphate. According to Lee and Tan (2002), demineralization can be carried out microbiologically that dissolve minerals found in shrimp shells through lactic acid fermentation process. Lactic acid bacteria included in the class gram-positive bacteria, not spore, rod-shaped or round, not respiring and optimum growth temperature ranges from 20 to $40{ }^{\circ} \mathrm{C}$. The special properties of lactic acid bacteria are able to grow on sugar, alcohol and high salt, grows at $\mathrm{pH} 3.8$ to 8.0. Lactobacillus is a probiotic organism that has a lot of important capabilities, including the ability to survive in the colony of cells, bacteriocin which works opposite to the growth of pathogens (Oyetayo, et al., 2001). The protein contained in the liquid waste from the extraction of chitin generally in the form of amino sugar is a glucosamine-forming component. Glucosamine is known to have a very important function in the process of growth and health of livestock, which in turn can affect the quality of the meat, whether physical, chemical, and microbiological.

To overcome the limitations of the material feed, Soehadji (1993) suggested that the development program in the livestock sub-sector vision of an environmentally friendly should be able to optimize the utilization of natural resources, especially the utilization of industrial waste, agricultural waste and fisheries. Waste fishing industry potential for development in the provision of alternative feed ingredients, include frozen shrimp processing waste in the form of skin, head and tail of the shrimp. Shrimp waste protein contains about 25 to $40 \%, 45 \%$ calcium carbonate and chitin about 15 to $20 \%$. Shrimp waste also contains carotenoid (color pigment) in the form astaxantine which is pro-vitamin $\mathrm{A}$ for the formation of a yellowish color. With this potential, it is expected the shrimp waste utilization can be optimized for production of chitin, as well as the production of proteoglycans as a feed supplement in poultry rations, especially native chicken.

Super native chicken is one kind of poultry meat producer is superior. Growth is relatively fast since the age of one week to six weeks. At three weeks old when his body was stocky and solid, super-old chicken six weeks already as big as the adult chicken, and if maintained until the age of 8 weeks of weight can reach nearly $2 \mathrm{~kg}$. In Indonesia the chicken super generally marketed at age 6 or 7 weeks on a live weight of between 1.3 to $1.6 \mathrm{~kg}$ (Rasyaf, 1995). The rapid growth will not arise if not supported by a diet containing protein and amino acids are balanced according to the needs of the chicken. Therefore the provision of feed supplement is important in order to improve the efficiency of the ration.

The research aims to obtain the amount of use of the product (energy-protein-concentrate) in a super chicken rations through the measurement of the performance (weight gain, feed intake and feed efficiency), as well as the production of carcass (carcass weight and meat). Usefulness of research is in order to utilize liquid waste extraction of chitin to be form a glucosamine as a source of energy protein (EPC) in order to support the productivity and quality of chicken meat, and simultaneously realize the development of environmentally sound awareness.

\section{RESEARCH METHODS}

1. Production of energy-protein-concentrates (EPC),including microbiological shrimp waste fermentation using Bacillus licheniformis 3\% for 2 days and Lactobacillus sp. $1 \%$ for 2 days, then performed the extraction, binderring with sulfate ions, and compaction with carbohydrates (corn starch, tapioca, and jelly stem). Liquid product extraction crystallized with tapioca as much as $75 \%$ (w / v) plus cornstarch $24.8 \%(\mathrm{w} / \mathrm{v})$ and jelly stem $0.2 \%(\mathrm{w} / \mathrm{v})$ and then heated at a temperature of $50^{\circ} \mathrm{C}$.

2. Test ration (Feeding Trial).Chickens used in this experiment is a native chickenone day old tail number 120 is obtained from the Center for Development of Livestock Breeding Poultry, Jatiwangi, Majalengka, and Westof Java. Prior to the experiment, chickens are numbered for ease of recording, and weighed beforehand to determine initial body weight, and then calculated the coefficient of variation (below 10 percent). Cages used are cage system with a size of $0.7 \mathrm{~m} \times 0.8 \mathrm{~m}$ to 5 chickens, as many as 24 units. 
The ration treatment used in this experiment consisted of:

1. $\mathrm{Rb}=$ basal diet, ration containing no $\mathrm{EPC}(18.5 \%$ protein and metabolizable energy $2,800 \mathrm{kcal} / \mathrm{kg}$.

2. $\mathrm{R} 1=99 \% \mathrm{Rb}+1 \% \mathrm{EPC}$.

3. $\mathrm{R} 2=98 \% \mathrm{Rb}+2 \% \mathrm{EPC}$.

4. $\mathrm{R} 3=97 \% \mathrm{Rb}+3 \% \mathrm{EPC}$.

5. $\mathrm{R} 4=96 \% \mathrm{Rb}+4 \% \mathrm{EPC}$.

6. $\mathrm{RS}=$ standard ration, ration containing no EPC with

$21.5 \%$ protein and metabolizable energy of 3,000 $\mathrm{kcal} / \mathrm{kg}$.

Feed materials making up the ration consists of: yellow corn, fine bran, soybean meal, coconut meal, fish meal, dicalcium phosphate, $\mathrm{CaCO}_{3}$, coconut oil, premix, and EPC. The basal diet ( $\mathrm{Rb})$ and the standard ration (RS) is based on Scott et al. (1982).

\section{Stages Experiment}

a) The preparation phase, covering the supply of feed ingredients used, supply of equipment, cages and equipment preparation and procurement of livestock experiments.

b) The maintenance phase, which includes the provision of rations, drinking water, vaccinations and medicines. Maintenance was carried out for 8 weeks.

c) Phase gathering and recording data during maintenance, starting with day-old chicken weighed to determine the initial weight.
Measurement of feed consumption, body weight gain and feed efficiency were made every week.

d) Post-maintenance phase, which is weighing the weight of the end, cutting the chicken and carcassed.

Experiments conducted an experiment using a completely randomized design (CRD) consisting of 6 treatments rations and each repeated four times, and each experimental unit consisted of five chickens. Data were analyzed by analysis of variance, the differences among the treatments with Duncan Multiple Range Test.

\section{Variables Observed}

a) Consumption of ration (g/ind.)

b) Weight gain ( $\mathrm{g} /$ ind.)

c) Efficiency of ration (\%).

d) Weight of Life /ind,

e) The weight of carcass

\section{RESULTS AND DISCUSSION}

The experiment begins with step perform bioprocess shrimp waste by using Bacillus licheniformis 3\% for 2 days, and Lactobacillus sp. $1 \%$ for 2 days, then performed the extraction, binderring with sulfate ions, and compaction with carbohydrates in order to obtain EPC (energy-protein concentrate). EPC used as a feed supplement that was added to the ration native chicken, and measurement of the performances.

Table.1: Changes in $\mathrm{pH}$ in the extraction process Glucosamine

\begin{tabular}{lcc}
\hline Stages Process & $\mathrm{pH}$ & Properties of Changes \\
\hline Initial substrate (shrimp waste) & 6.8 & \\
Deproteinasiwith Bacillus licheniformis & 8.4 & \\
Demineralize with Lactobacillus $s p$ & 6.2 & \\
Liquid extract & 5.8 & \\
Binderring with & & Acid to base +++ \\
$\quad \mathrm{NaHSO}_{4}$ & $6.2-7.6$ & Acid to base +++ \\
$\mathrm{K}_{2} \mathrm{SO}_{4}$ & $5.2-7.6$ & Acid to base ++ \\
$\left(\mathrm{NH}_{4}\right)_{2} \mathrm{SO}_{4}$ & $7.0-7.1$ & \\
\hline
\end{tabular}

From Table 1 it appears that the use of the type of binder potassium sulphate and sodium hydrosulfate have a tendency to changes in $\mathrm{pH}$ that is stronger than the acid to alkaline compared with ammonium sulphate. This indicates that the addition of various types of binders on chitin extraction wastewater will increase the $\mathrm{pH}$ value of the waste products that are acidic ( $\mathrm{pH} \mathrm{5.8)} \mathrm{to} \mathrm{tend} \mathrm{to} \mathrm{be}$ neutral to alkaline until the $\mathrm{pH}$ value of 7.6.

The experimental results of this phase indicates that the final $\mathrm{pH}$ of the product naturate results $\mathrm{NaHSO}_{4}$ binder was 6 , while of ammonium sulfate the $\mathrm{pH}$ of 7 and the results by potassium sulphate $\mathrm{pH}$ of 10 . According to
Lehninger (1992), an amino acid that is formed, which is acidic, is aspartate and glutamate $(\mathrm{pH} 4)$, while the amino acid lysine that was alkaline $(\mathrm{pH} 10.5)$, arginine $(\mathrm{pH}$ 12.5), cysteine ( $\mathrm{pH} \mathrm{8.4),} \mathrm{and} \mathrm{tyrosine} \mathrm{(} \mathrm{pH} \mathrm{10,5).} \mathrm{Alkaline}$ of amino acids is required more essential by poultry than non essensial aspartic and glutamic acid because it can be formed in the bird's body.

If the terms of its characteristics as a constituent amino acids, alkaline products that tend to be more profitable. This is because many types of amino acids essensial alkaline, such as lysine. Fermentation products are generally acidic. Given the products that tend to be 
alkaline so quickly to help neutralize the atmosphere of the intestines, which is more profitable.

Utilization extract glucosamine shrimp waste through the establishment of an effort naturate waste protein into amino acid source products that will be worth biologically. Liquid extraction product crystallized with tapioca as much as $75 \%(\mathrm{w} / \mathrm{v})$ plus cornstarch $24.8 \%$ $(\mathrm{w} / \mathrm{v})$ and in order to stem a $0.2 \%(\mathrm{w} / \mathrm{v})$ and then heated at a temperature of $50^{\circ} \mathrm{C}$, glucosamine products can be used as a source of feed supplements in the form of EnergyProtein-Concentrate (EPC) which is an important economic value to add to their repertoire of alternative feed ingredients are added to chicken feed.

\section{Effect of Treatment of Consumption and Efficiency of Ration of Native Chicken}

Performance ofnative chicken through growth (weight gain) and is influenced by feed intake. In order to determine the efficiency of feed, can be measured by the efficiency of ration.The treatment in this experiment was the degree of the use of energy-protein-concentrates (EPC) respectively of $0 \% ; 1 \% ; 2 \% ; 3 \% ; 4 \%$; and standard ration through the measurement of the consumption and feed efficiency, and the results are shown in Table 2.

Table.2: Mean Consumption and Efficiency of Rations in each Treatments

\begin{tabular}{|c|c|c|}
\hline \multirow{2}{*}{ Treatment } & \multicolumn{2}{|c|}{ VariableObserved } \\
\hline & $\begin{array}{c}\text { Feed Consumption } \\
\ldots \ldots . .(\mathrm{g}) \ldots \ldots \ldots \ldots .\end{array}$ & $\begin{array}{c}\text { Efficiency of Rations } \\
\text {........(\%)........ }\end{array}$ \\
\hline $\mathrm{R}_{\mathrm{b}}(\mathrm{CP} 18.5 \% ; \mathrm{ME} 2,800 \mathrm{kcal} / \mathrm{kg})$ & $2,015^{\mathrm{a}}$ & 34.98 a \\
\hline $\mathrm{R}_{1}\left(99 \% \mathrm{R}_{\mathrm{b}}+1 \% \mathrm{EPC}\right)$ & $2,017^{a}$ & $40.89^{\mathrm{a}}$ \\
\hline $\mathrm{R}_{2}\left(98 \% \mathrm{R}_{\mathrm{b}}+2 \% \mathrm{EPC}\right)$ & $1,988^{\text {a }}$ & 42.68 ab \\
\hline $\mathrm{R}_{3}\left(97 \% \mathrm{R}_{\mathrm{b}}+3 \% \mathrm{EPC}\right)$ & $1,978^{\text {a }}$ & 54.09 bc \\
\hline $\mathrm{R}_{4}\left(96 \% \mathrm{R}_{\mathrm{b}}+4 \% \mathrm{EPC}\right)$ & $1,970^{\mathrm{a}}$ & $61.31 \mathrm{c}$ \\
\hline 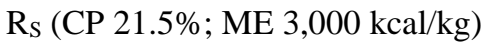 & $1,975^{a}$ & $62.06^{\mathrm{c}}$ \\
\hline
\end{tabular}

The experimental results in Table 2 shows the differences in feed efficiency of each treatment, but showed no difference in feed intake. The highest efficiency of ration obtained in RStreatment that was equal to $62.06 \%$, and R354.09\%, and R4amounting to $61.31 \%$. The lowest efficiency obtained in the treatment of $\mathrm{Rb}$ was $34.98 \%$ and R1 equal to $40.89 \%$. Statistical test through Analysis of Variance conducted to determine the effect of treatment on feed consumption and efficiency of ration. Duncan test results showed that the treatment did not show any significant differences ( $p>0.05$ ) on feed consumption, but seen significant difference $(P<0.05)$ efficiency of ration.Feed consumption were almost identical indicating that the addition of EPC origin waste liquid waste shrimp feed super chicken, no influence on feed consumption. Feed intake is strongly influenced by the palatability of the feed materials making up the ration. As proposed by the Church and Pond (1979) that the palatability of feed is an important factor that determines the level of feed intake and palatability depend on smell, taste, color and texture of the material making up the feed ration. Treatment rations no significant effect on consumption, showed that the addition of EPC up to the level of $4 \%$, does not cause physical differences and flavor that is not liked by the chicken, so it does not cause a decrease in palatability.
Treatment RS and R4 produce feed efficiency value was significantly higher than with the treatment of $\mathrm{Rb}, \mathrm{R} 1$ and $\mathrm{R} 2$; but did not show significant differences compared with the treatment of R3. As for the treatment of R2, R1, and $\mathrm{Rb}$, and between R2 and R3 did not show significant differences ( $p>0.05$ ). Values super chicken feed efficiency increased with the addition of $3 \%$ EPC (R3). Use of EPC $3 \%$ (R3) in the feed ration generating efficiency value which was equivalent to the standard ration (RS) containing $21.5 \%$ protein and metabolizable energy of 3,000 kcal / $\mathrm{kg}$ although $\mathrm{R} 3$ ration containing only $18.5 \%$ protein and metabolic energy in $2,800 \mathrm{kcal} /$ $\mathrm{kg}$. Increased feed efficiency value indicates the increased biological value, so that the impact on growth and feed efficiency. As it has been known that the feed intake in each treatment was almost the same, but with the addition of EPC increased growth, particularly in R3 and R4were equivalent to the standard ration (RS). In line with the opinion of Winarno (1980) and Gumbira (1989) that biological treatment processes can transform an organic material into other useful products and added value better, especially by utilizing the biological events that in the life cycle of all beings experiencing long stage between biolysis biosynthesis and other events. Products that can be produced from a biological process is microbial cells or biomass, enzymes, metabolic primary and secondary metabolic and chemical compounds by microbes results 
bioprocess (Ansori, 1989). Thus the value of highefficiency ration was reflected in higher growth, indicating the high quality and efficiency ration (Bautrif,
1990). Effect of Treatment of Weight Gain Native Chicken Super Mean weight gain during the study native chickencan be seen Table 3 .

Table.3: Effect of Treatment on Growth Weights of Native chicken

\begin{tabular}{|c|c|}
\hline Treatment & $\begin{array}{c}\text { Mean weight gain } \\
\ldots . . .(\mathrm{g} / \mathrm{e}) \ldots \ldots \ldots .\end{array}$ \\
\hline $\mathrm{R}_{\mathrm{b}}(\mathrm{CP} 18.5 \% ; \mathrm{ME} 2,800 \mathrm{kcal} / \mathrm{kg}$ & $176.25^{\mathrm{a}}$ \\
\hline $\mathrm{R}_{1}\left(99 \% \mathrm{R}_{\mathrm{b}}+1 \% \mathrm{EPC}\right)$ & $206.25^{a}$ \\
\hline $\mathrm{R}_{2}\left(98 \% \mathrm{R}_{\mathrm{b}}+2 \% \mathrm{EPC}\right)$ & $211.875^{\mathrm{a}}$ \\
\hline $\mathrm{R}_{3}\left(97 \% \mathrm{R}_{\mathrm{b}}+3 \% \mathrm{EPC}\right)$ & $267.50^{\text {ab }}$ \\
\hline $\mathrm{R}_{4}\left(96 \% \mathrm{R}_{\mathrm{b}}+4 \% \mathrm{EPC}\right)$ & $301.875^{\mathrm{b}}$ \\
\hline $\mathrm{R}_{\mathrm{S}}(\mathrm{CP} 21.5 \%$; ME 3,000 kcal/kg) & $306.25^{\text {b }}$ \\
\hline
\end{tabular}

Table 3 shows that weight gain in the treatment of RS, and R4, did not show any significant differences ( $\mathrm{p}>$ 0.05 ), but both were significantly ( $\mathrm{p}<0.05)$ higher compared with the treatment of $\mathrm{Rb}, \mathrm{R} 1$ and R2. R3 treatment was not significantly different ( $p>0.05)$ by treatment with R4 and RS. Weight gain native chickenincreased with the addition of $3 \% \mathrm{EPC}$ in the ration.

Use of EPC 3\% (R3) in the diet result in weight gain which is equivalent to the standard ration (RS) with a protein content of $21.5 \%$ and metabolizable energy of $3,000 \mathrm{kcal} / \mathrm{kg}$ although R3 ration containing only $18.5 \%$ protein and metabolic energy in $2,800 \mathrm{kcal} / \mathrm{kg}$. This is because the rations containing EPC products biological process chemical change of the compound that is bound to compounds that are simpler and easier to digest due to the presence of microbial activity so as to provide a positive effect on the growth of native chicken (Schneider and Flat, 1975; Stanton and Yeoh, 1976).

Effect of Treatment of Life and Carcass Weights on Native Chicken

The average live weight and carcass weight during the study can be seen Table 4 .

Table.4: Effect of Treatment of Life and Carcass Weights on Native Chicken

\begin{tabular}{|c|c|c|}
\hline \multirow[b]{2}{*}{ Treatment } & \multicolumn{2}{|c|}{ VariableObserved } \\
\hline & $\begin{array}{l}\text { Life Weight } \\
\ldots \ldots .(\mathrm{g}) \ldots \ldots \ldots\end{array}$ & $\begin{array}{c}\text { Carcass Weight } \\
\ldots . . . .(\mathrm{g}) \ldots \ldots \ldots\end{array}$ \\
\hline $\mathrm{R}_{\mathrm{b}}(\mathrm{CP} 18.5 \% ; \mathrm{ME} 2,800 \mathrm{kcal} / \mathrm{kg}$ & $322.5^{\mathrm{a}}$ & $190.0^{\mathrm{a}}$ \\
\hline $\mathrm{R}_{1}\left(99 \% \mathrm{R}_{\mathrm{b}}+1 \% \mathrm{EPC}\right)$ & $352.5^{\mathrm{a}}$ & $240.0^{\mathrm{a}}$ \\
\hline $\mathrm{R}_{2}\left(98 \% \mathrm{R}_{\mathrm{b}}+2 \% \mathrm{EPC}\right)$ & $362.5^{\text {a }}$ & $252.5^{\text {ab }}$ \\
\hline $\mathrm{R}_{3}\left(97 \% \mathrm{R}_{\mathrm{b}}+3 \% \mathrm{EPC}\right)$ & $412.5^{\mathrm{b}}$ & $316.5^{b}$ \\
\hline $\mathrm{R}_{4}\left(96 \% \mathrm{R}_{\mathrm{b}}+4 \% \mathrm{EPC}\right)$ & $445.0^{\mathrm{b}}$ & $312.5^{b}$ \\
\hline 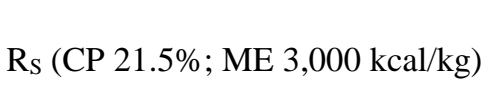 & $452.5^{\mathrm{b}}$ & $275.0^{\mathrm{b}}$ \\
\hline
\end{tabular}

Table 4 shows that the weight of life in the treatment of RS, R4 and R3 did not show any significant differences ( $>0.05$ ), but all three significantly $(p<0.05)$ higher compared with the treatment of Rb, R1 and R2. Super chicken live weight increased with the addition of $3 \%$ EPK (R3).

Use of EPC $3 \%(\mathrm{R} 3)$ in the diet resulted in live weight equivalent to the standard ration (RS) with a protein content of $21.5 \%$ and metabolizable energy of 3,000 kcal / $\mathrm{kg}$ although R3 ration containing only $18.5 \%$ protein and metabolic energy $2,800 \mathrm{kcal} / \mathrm{kg}$. This is because the rations containing EPC products biological process chemical change of the compound that is bound to compounds that are simpler and easier to digest due to the presence of microbial activity so as to provide a positive 
effect on live weight of native chicken(Schneider and Flat, 1975; Stanton and Yeoh, 1976).

Carcass weights of native chicken with the use of EPC2\% (R2) in the ration, equivalent to the standard ration (RS) with a protein content of $21.5 \%$ and metabolizable energy of 3,000 kcal / $\mathrm{kg}$ although $\mathrm{R} 2$ only contain protein ration of $18.5 \%$ and metabolic energy $2,800 \mathrm{kcal} / \mathrm{kg}$.

\section{CONCLUSIONS AND RECOMMENDATIONS}

\section{Conclusion:}

(1) The use of energy-protein concentrates (EPC) in ration chicken feed intake super generate the same response.

(2) The use of energy-protein-concentrates (EPC) in a super chicken feed at a rate of $3 \%$ can improve weight gain, live weight and carcass weight, as well as the efficiency of feed utilization.

(3) Rations with $18.5 \%$ crude protein and metabolizable energy $2,800 \mathrm{kcal} / \mathrm{kg}$ which is coupled with the $3 \%$ EPC produces performantnative chicken which is equivalent to the standard ration $(20.5 \%$ crude protein and metabolizable energy of $3,000 \mathrm{kcal} / \mathrm{kg}$ ).

\section{Suggestion:}

Formulation and preparation of rations native chicken suggested using $18.5 \%$ crude protein and metabolizable energy 2,800 kcal / $\mathrm{kg}$ plus the energy-proteinconcentrates (EPC) $3 \%$ of the product of biological processes shrimp waste extraction.

\section{REFERENCES}

[1] Ansori, R. 1989. Pengantar Teknologi Fermentasi. Pusat Antar Universitas IPB, Bogor.

[2] Bautrif, E. 1990. Recent Development in Quality Evaluation. Food Policy and Nutrion Division, FAO, Rome.

[3] Cira, L.A., S Huerta, I Guerrero, R Rosas, G.M Hall and K Shirai. 2000. Scalling up of Lactic Acid Fermentation of Prawn Waste in Packed-Bed Column Reactor for Chitin Recovery. In : Advan Chitin Sci., vol. 4, Peter, M.G., A Domard, and R.A.A. Muzzarelli (eds).

[4] Degusa. 2002. Amino Acid in Animal Nutrition. Publishing House Coral Sanivet, Bucharest.

[5] Gumbira, S.E. 1987. Bioindustri Penerapan Teknologi Fermentasi. Pusat Antar Universitas Bioteknologi. IPB, Bogor.

[6] Lee, V and E. Tan. 2002. Enzymatic Hydrolysis of Prawn Shell Waste for The Purification of Chitin. Departement of Chemical Engineering, Loughborough University.
[7] Oyetayo, V.O., Adetuyi, F.C., and F.A. Akinyosoye. 2001. Safety and Protective Effect of Lactobacillus acidophilus and Lactobacillus casei Used as Probiotic Agent In Vivo. Department of Microbiology. Federal University of Technology, Akure.

[8] Rao, M.B., A.M. Tanksale, M.S. Ghatge and V.V. Deshpande. 1998. Molecular and Biotechnological Aspect of Microbial Proteases. J. Microbiol. Mol. Biol. Rev. 62(3)

[9] Rasyaf, M. 1995. Beternak Ayam Ras Pedaging. Penebar Swadaya, Jakarta.

[10] Schneider, B.H. dan W.P. Flatt. 1975. The Evaluation of Feeds Through Digestibility Experiment. The University of Georgia Press, New York.

[11] Scott, M.L., M.C. Nesheim and R.J. Young. 1982. Nutrition of the Chicken. M.L. Scott and Associate, New York.

[12] Sklan, D. and S. Hurwitz, 1980. Protein Digestion and Absorption in Young Chick and Turkey. J. Nutrition 110:139-144.

[13] Soehadji. 1993. Kebijaksanaan Pengembangan Teknik Unggas di Indonesia : Pelita VI. Prosiding Seminar Nasional Pengembangan Ternak Ayam Buras Melalui Wadah Koperasi Menyongsong PJPT II. Unpad, Bandung.

[14] Stanton, W.R., and A. Wallbridge. 1989. Fermented Food Process. Microorganisme in solid Substrate fermentation. Proceeding of The first Asean Workshop, Bandung.

[15] Winarno, F.G. 1980. Kimia Pangan dan Gizi. PT. Gramedia, Jakarta. 